析出強化型 $\mathrm{Ni}$ 基合金の加工硬化機構に基づくクリープ余寿命推定法 生沼 駿* 高久 歴** 中谷 祐二郎*

竹山 雅夫***

\title{
Creep Residual Life Estimation Method Based on Strain Hardening Mechanism for Precipitation Strengthened Ni-Based Alloy
}

by

\author{
Shun OinUma*, Reki TAKAKU**, Yujiro NAKATANI* and \\ Masao TAKEYAMA***
}

To establish the creep life prediction method for Ni-based alloys, the microstructure, hardness and dislocation density measurement was done for various creep damaged samples of $\gamma^{\prime}-\mathrm{Ni}_{3} \mathrm{Al}$ precipitation strengthened alloy, TOS $1 X$ 2. The hardness and dislocation density of creep interrupted and ruptured samples at $700^{\circ} \mathrm{C}$ and $750^{\circ} \mathrm{C}$ increased with creep strain and creep time. TEM analysis showed that large amount of dislocations induced by creep was present in $\gamma$ matrix, and $\gamma$ ' precipitates were almost free from dislocation. The hardness increase at gauge portion of specimens showed linear increase with square root of dislocation density, suggesting that hardening by creep damage obeys the BaileyHirsch's strain hardening relationship. Based on this strain hardening relationship and combining the creep constitutive equation, the creep residual life of interrupted specimens was estimated with high accuracy from measured hardness.

\section{Key words:}

A-USC, Superalloy, Creep damage, Hardness, Dislocation density, Strain hardening

\section{1 緒言}

火力発電システムは, 今後も世界のエネルギー供給に おいて重要な役割を担う一方で, $\mathrm{CO}_{2}$ を多く排出すること から，各国の環境規制が強まっている．今後は $\mathrm{CO}_{2}$ 排出 量が少ない高効率発電技術の開発が必要であり，その一 つの手段として, $1700^{\circ} \mathrm{C}$ 級ガスタービンコンバインドサ イクル発電や, $700^{\circ} \mathrm{C}$ 級先進超々臨界圧火力発電 (A-USC) などに代表される高温サイクルの技術開発が進められて (る ${ }^{1)-5)}$. これらの機器の高温部品には, 高温強度に優れ る $\gamma^{\prime}-\mathrm{Ni}_{3}(\mathrm{Al}, \mathrm{Ti})$ 相を主たる析出強化相とする $\mathrm{Ni}$ 基合金が 選定されている. 特に, タービンロータ用の大型鍛造品で は，優れた熱間鍛造性，溶接性，クリープおよび疲労強度 が要求されるため, それらを満足する TOS $1 X-2, L T E S 700 R$, FENIX700 などの合金が国内で開発されている ${ }^{1), 4), 6) .}$

析出強化型 $\mathrm{Ni}$ 基超合金の開発課題のひとつに，高温長 時間運転後のクリープ損傷評価法の構築がある ${ }^{7)}$. 従来か ら使用されている高 $\mathrm{Cr}$ フェライト系耐熱鋼の場合，簡便 で非破壊評価が可能な硬さ法が広く適用されている。高 Cr フェライト系而熱鋼は, 新材のマルテンサイト組織中 の転位が長時間時効およびクリープ損傷により回復し, 転位密度が低下することにより軟化することが知られて いる ${ }^{8)-10)}$. 一方，析出強化型 $\mathrm{Ni}$ 基合金や $\mathrm{Ni}-\mathrm{Fe}$ 基合金は Alloy 617, HR6W, Alloy $740 H$ 合金などのボイラ用材料に
関してクリープ損傷に伴う硬さ変化が評価されており, いずれもクリープの進行に伴い硬化すると述べられてい る ${ }^{11-13)}$. これは, クリープ変形に伴う加工硬化が原因で あると述べられているものの, 転位組織観察や転位密度 測定などにより定量的に立証されたものではない. Ni 基 合金やステンレス鋼などのオーステナイト系合金は, 室 温や高温で引張変形を受けた試験片に対して, 転位密度 の増加による加工硬化が確認されているが 14),15)，クリー プ変形に対しては確認されていない. 寸なわち, Ni 基合 金はクリープ損傷に伴う硬化が転位論的根拠を基に明ら かにされているとは言えず, 硬さ法による寿命評価方法 が理論的，実用的に確立しているとは言い難い.

以上の背景から, 本研究では析出強化型 $\mathrm{Ni}$ 基合金の硬 さ法によるクリープ損傷評価法を構築することを目指し， 複数条件のクリープ中断および破断試験片の転位組織, 転位密度および硬さを評価し, クリープ損傷に伴う硬化 機構を明確化することとした.また, 硬さ測定によってク リープ余寿命を推定する方法の構築と検証を行った。

\section{2 実 験 方 法}

\section{$2 \cdot 1$ 供試合金}

対象合金は，Alloy 617 合金をベースに Al，Ti，Ta およ び $\mathrm{Nb}$ を添加し， $\gamma$ ’相を粒内析出させて高強度化した口

$\dagger \quad$ 原稿受理 令和2年1月4日 Received Jan.4, 2020 @2020 The Society of Materials Science, Japan

* 正 会 員 東芝エネルギーシステムズ(株) エネルギーシステム技術開発センター テ230-0045 横浜市鶴見区

Energy Systems R\&D Center, Toshiba Energy Systems \& Solutions Corporation, Tsurumi-ku, Yokohama 230-0045.

**＼cjkstart東芝エネルギーシステムズ(株) エネルギーシステム技術開発センター ○230-0045 横浜市鶴見区

Energy Systems R\&D Center, Toshiba Energy Systems \& Solutions Corporation, Tsurumi-ku, Yokohama 230-0045.

*** 東京工業大学物質理工学院 干152-8550 東京都目黒区大岡山

School of Materials and Chemical Technology, Tokyo Institute of Technology, Meguro-ku, Tokyo 152-8550. 
一夕用鍛造 Ni 基超合金 TOS $1 X-2$ である ${ }^{16), 17) . ~ T a b l e ~} 1$ に 公称化学成分を示寸．供試材は，Vacuum Induction Melting (VIM）および Electro-Slag Remelting (ESR) のダブルメ ルト法によって溶製後，熱間鍛造により直径 $1100 \mathrm{~mm}$ ，全 長 $2400 \mathrm{~mm}$ のロータ形状に成形した, 製品重量 14ton のロ 一タ素材である. クリープ試験用の試験片は, 本素材の中 心部から, 引張応力軸が接線方向となるように採取した。

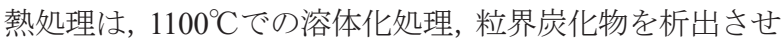

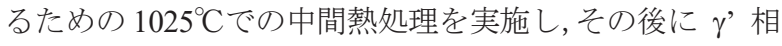
を析出させる $800^{\circ} \mathrm{C}$ と $750^{\circ} \mathrm{C}$ での 2 段時効処理を実施した. Fig.1 に TOS1X-2 の熱処理後の組織を示す. 組織はオース テナイトの等軸粒組織を示し, 粒内には直径数 $10 \mathrm{~nm}$ の微 細球状の $\gamma^{\prime}$ 相が析出している.

Table 1 Nominal composition of studied alloy (mass \%).

\begin{tabular}{cccccccccc}
\hline & $\mathrm{Ni}$ & $\mathrm{C}$ & $\mathrm{Cr}$ & $\mathrm{Mo}$ & $\mathrm{Co}$ & $\mathrm{Al}$ & $\mathrm{Ti}$ & $\mathrm{Ta}$ & $\mathrm{Nb}$ \\
\hline $\begin{array}{c}\text { UNS N06617 } \\
\text { "Alloy 617" }\end{array}$ & Bal. & 0.1 & 22 & 9 & 12.5 & 1.1 & 0.3 & & \\
\hline "TOS1X-2" & Bal. & 0.05 & 18 & 9 & 12.5 & 1.25 & 1.35 & 0.1 & 0.3 \\
\hline
\end{tabular}

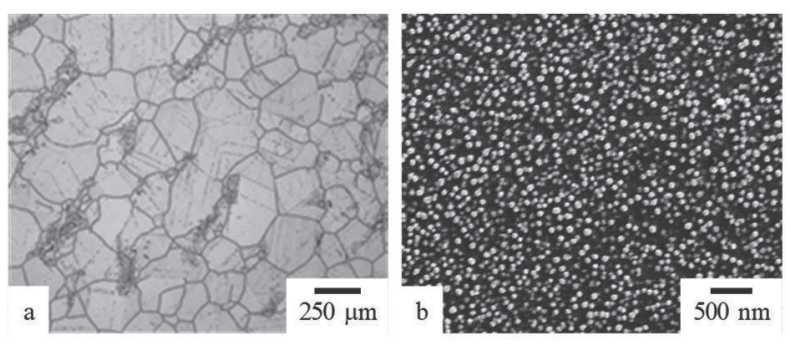

Fig. 1 Microstructure of as heat treated TOS1X-2; (a) optical micrograph and (b) FE-SEM secondary electron image.

\section{$2 \cdot 2$ クリープ中断および破断試験}

クリープ中断および破断試験には，直径 $6 \mathrm{~mm} ，$ 標点間 距離 30mm の JIS14 号試験片を使用した. クリープ破断試 験は 700 $800^{\circ} \mathrm{C}, 100 \sim 400 \mathrm{MPa}$ の広範囲に渡る温度, 応 力条件で実施し, 最長破断時間が約 40,000 時間の試験片 を得た.クリープ中断試験は $700^{\circ} \mathrm{C}$ に $400 \mathrm{MPa}$ と $320 \mathrm{MPa}$ の 2 条件, $750^{\circ} \mathrm{C}$ に $260 \mathrm{MPa}$ と $200 \mathrm{MPa}$ の 2 条件の計 4 条件で実施した。それぞれの温度応力条件における破断 寿命の 30〜80\%にて中断した.

種々のクリープ中断および破断試験片について，各温 度での単純時効に相当するねじ部，およびクリープ損傷 を受けた平行部のビッカース硬さを測定した。測定にお ける荷重は 49N，保持時間は $10 \mathrm{sec}$ とした。また，クリー プ損傷を受けた平行部に関しては，さらに X 線回折法 （XRD）による転位密度測定を実施した．X 線回折は， Fig.2 に示す通り各中断試験片の平行部中心，および破断 試験片の破断部近傍を中心位置として, 試験片を回転さ せながら $\phi 6 \mathrm{~mm}$ に相当する領域を測定し, 多数の結晶粒 からの情報を得た．X 線源には Co K $\alpha$ 管球を使用した。転 位密度は (111), (200), (220), (311), (222)の各結晶面から 得た X 線プロファイルを用いて, Williamson-Hall 法によ
る解析により格子ひずみ\&よおよび結晶子サイズ $D$ を求め, (1)および(2)式より転位密度 $\rho$ を計算した ${ }^{18)-20):}$

$$
\begin{aligned}
& \frac{\beta \cos \theta}{\lambda}=\frac{0.9}{D}+\frac{2 \varepsilon_{L} \sin \theta}{\lambda} \\
& \rho=16.1\left(\frac{\varepsilon_{L}}{b}\right)^{2}
\end{aligned}
$$

ここで, $\theta$ はブラッグ角, $\lambda$ はX 線波長, $b$ はバーガース ベクトル， $\beta$ はX 線回折のピーク半值幅である.

(a)

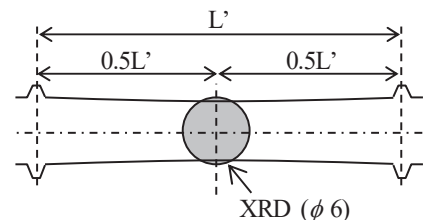

(b)

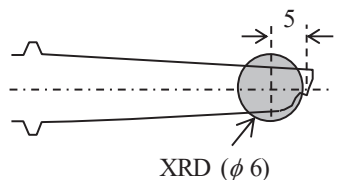

(mm)

Fig. 2 XRD analyzed area for (a) creep interrupted and (b) creep ruptured specimens.

\section{$3 \cdot 1$ クリープ損傷形態}

\section{3 実 験 結 果}

Fig. 3(a)および(b)に TOS1X-2 のクリープ破断強度と破 断材の延性を示す. $700^{\circ} \mathrm{C}$ での最長破断時間 $t_{\mathrm{r}}$ は $230 \mathrm{MPa}$ における $42,617 \mathrm{~h}$ であり， $750^{\circ} \mathrm{C}$ では $145 \mathrm{MPa}$ における $30,309 \mathrm{~h}$ である. 本合金は $700^{\circ} \mathrm{C}$ 以上の温度で $10^{4} \mathrm{~h}$ を超え ても，顕著なクリープ破断強度の低下は認められなかっ た.また特徴として, クリープ破断伸びや絞りが長時間側 まで高い值を示し，延性に優れていた。

Fig.4(a)に，本合金の最小クリープひずみ速度と応力の 関係，(b)に破断時間との関係を示す. 本合金の応力指数 $n$ は 700 $800^{\circ} \mathrm{C}$ に 6.3〜 7.8 であり, 試験温度および応力 範囲内において大きな差はなかった。 またひずみ速度の 低下に伴い破断時間が増加する Monkman-Grant の関係が 得られ，広い温度および応力範囲において同じ傾きを有 していた. 以上のクリープ破断特性から, 本合金のクリー プ試験条件範囲では, クリープの変形機構や変形の律速 過程に大きな変化がなかったものと推察される.

Fig. 5 に，新材 $(\mathrm{a}, \mathrm{b})$ および $750^{\circ} \mathrm{C} / 145 \mathrm{MPa}, t_{\mathrm{r}}=30,309 \mathrm{~h}$ ク リープ破断試験片のねじ部(c,d) と平行部つば近傍(e,f)の TEM 明視野像を示す. 新材は数 $10 \mathrm{~nm}$ 程度の非常に微細 な球状 $\gamma^{\prime}$ 相が分散析出しており, 初期転位は粒界に若干 認められる程度である.クリープ破断材のねじ部では粒 界の炭化物や粒内の $\gamma^{\prime}$ 相が粗大化し, 転位は粒界周辺お よび粒内ともにほとんど認められなかった. 一方, 平行部 では粒界および粒内に多くの転位が存在していた．粒内 転位は湾曲しており， $\gamma^{\prime}$ 粒子の周辺に絡みあうような形 態が多く認められることから， $\gamma^{\prime}$ 相は転位運動の障壁と して働いていると推察される. 

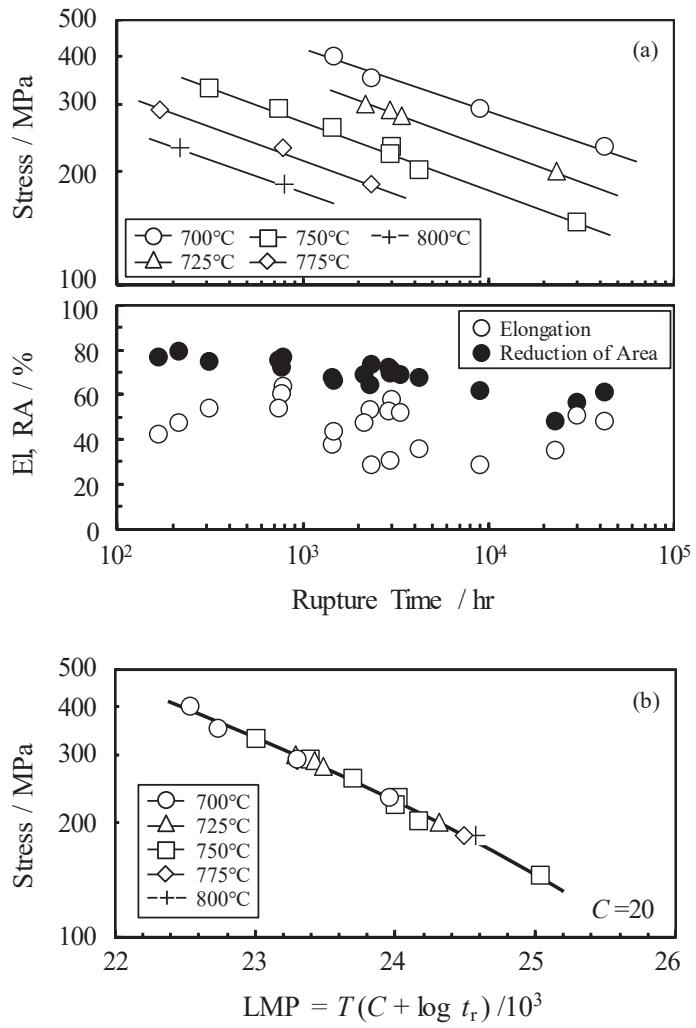

Fig. 3 Creep rupture strength and ductility of TOS1X-2 sorted by (a) rupture time and (b) Larson-Miller Parameter.

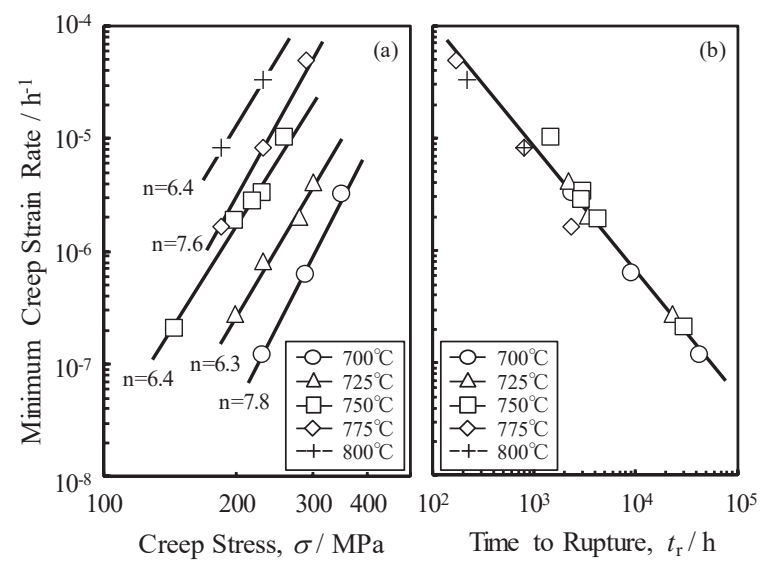

Fig. 4 Creep strain rate of TOSIX-2; (a) Relationship between minimum creep strain rate and creep stress and (b) MonkmanGrant relationship.

\section{$3 \cdot 2$ クリープ損傷に伴う硬さと転位密度の変化}

Fig. 6 に，クリープ中断および破断材のねじ部および平 行部のビッカース硬さを示す. 横軸は, 各条件におけるク リープひずみ $\varepsilon$ および時間 $t$ を，破断ひずみ $\varepsilon$ および破 断時間 $t_{\mathrm{r}}$ で規格化した值である. ねじ部の硬さは，クリー プひずみおよび時間の増加に伴う変化がほとんど認めら れなかった. 一方, 平行部の硬さはクリープひずみおよび 時間に伴い増加する傾向を示した。

Fig.7 に, ねじ部と平行部の平均硬さの差を $\Delta H V_{\mathrm{c}}$ と定義 し，規格化ひずみ $\varepsilon_{\mathrm{c}} / \varepsilon_{\mathrm{r}}$ および規格化時間 $t / t_{\mathrm{r}}$ で整理して 示す， $\Delta H V_{\mathrm{c}}$ は単純時効による組織変化，本合金の場合は 特に $\gamma^{\prime}$ 相の粗大化の影響を含まず, クリープによる変形

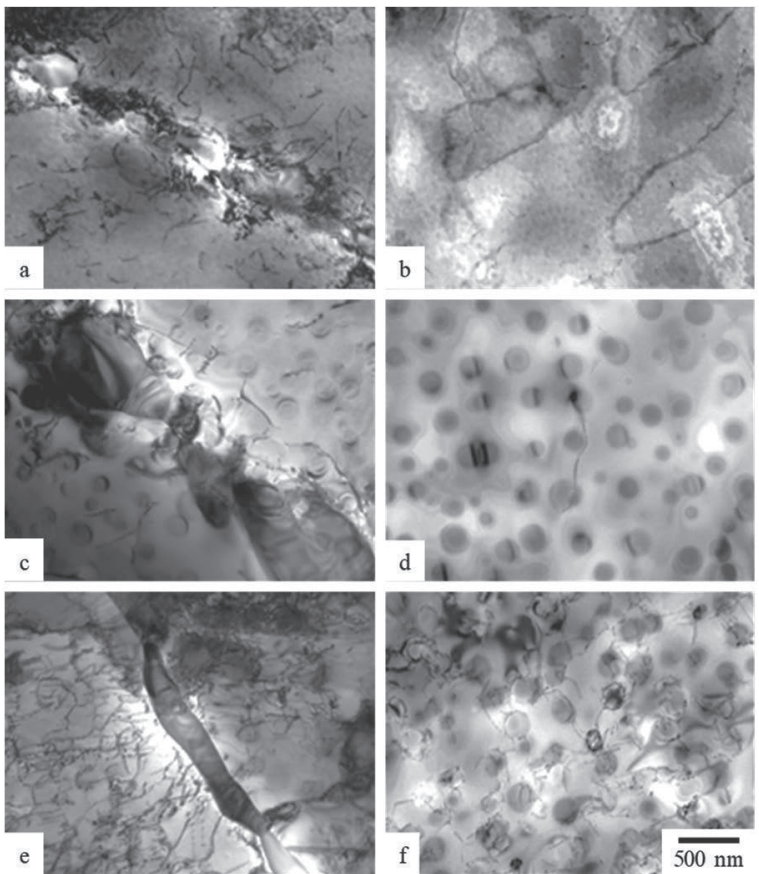

Fig. 5 TEM bright field images of (a,b) initial, (c,d) grip and (e,f) gauge portion of $750^{\circ} \mathrm{C} / 145 \mathrm{MPa}, \mathrm{t}_{\mathrm{r}}=30,309 \mathrm{~h}$ crept specimen; (a, $\mathrm{c}, \mathrm{e})$ Microstructure around grain boundary, $(\mathrm{b}, \mathrm{d}, \mathrm{f})$ Microstructure at grain interior.

に影響される值である。 $\Delta H V_{\mathrm{c}}$ は，クリープひずみおよび 時間の増加に伴い単調に増加した。 また $\Delta H V_{\mathrm{c}}$ は, 特に寿 命比 0.8 以上の領域において顕著な増加が認められた。

Fig. 8 に, クリープ中断および破断材の平行部にて測定 した転位密度 $\rho$ と, 規格化ひずみ $\varepsilon_{\mathrm{c}} / \varepsilon_{\mathrm{r}}$ および規格化時 間 $t / t_{\mathrm{r}}$ との関係を示す． $\rho$ のクリープひずみおよび時間依 存性は硬さと同様の傾向を示し，ひずみや時間の増加に 伴い増加した. また, 硬さと同様に, 特にクリープ寿命比 0.8 以上の領域において顕著な増加が認められた。

\section{4 考察}

\section{$4 \cdot 1$ クリープ損傷に伴う硬化機構}

破断材の TEM 組織観察結果から, 本合金はクリープ変 形に伴い転位が $\gamma$ 母相に導入される. そして転位密度は, クリープひずみとともに比較的単調に増加すること，ま た寿命比 0.8 以上において急激に増加することが特徴で あり, 後者はクリープ加速域の挙動に類似することから, クリープひずみの急増によるものと推察される. 組織, 硬 さおよび転位密度の結果から，本合金はクリープひずみ の増加に伴い転位が導入され，加工硬化したことは明ら かである. 加工硬化による材料強化分 $\tau$ は Bailey-Hirsch の式(3)の通り, 転位密度 $\rho$ の $1 / 2$ 乗に比例する ${ }^{21)-23) . ~}$

$$
\tau=\alpha G b \sqrt{\rho}
$$

ここで， $\alpha$ は材料定数である. Fig.9(a)に，XRD 測定に より得られたクリープ損傷材の硬さ増分 $\Delta H V_{\mathrm{c}}$ と格子ひ ずみ $\varepsilon$ と関係を, (b)に転位密度 $\rho$ の $1 / 2$ 乗との関係を 示す. 


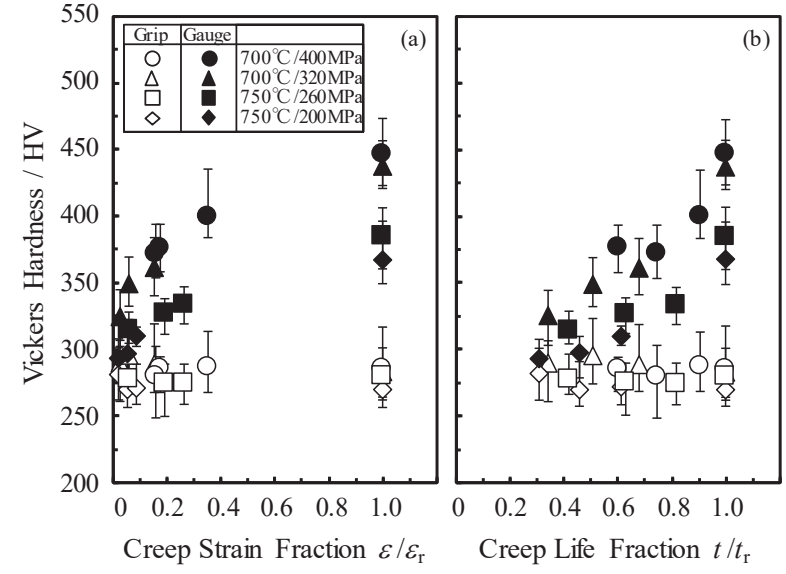

Fig. 6 Vickers Hardness of grip and gauge portions of specimens crept at $700^{\circ} \mathrm{C}$ and $750^{\circ} \mathrm{C}$ sorted by (a) creep strain fraction, $\varepsilon / \varepsilon_{\mathrm{r}}$ and (b) creep life fraction, $t / t_{\mathrm{r}}$.

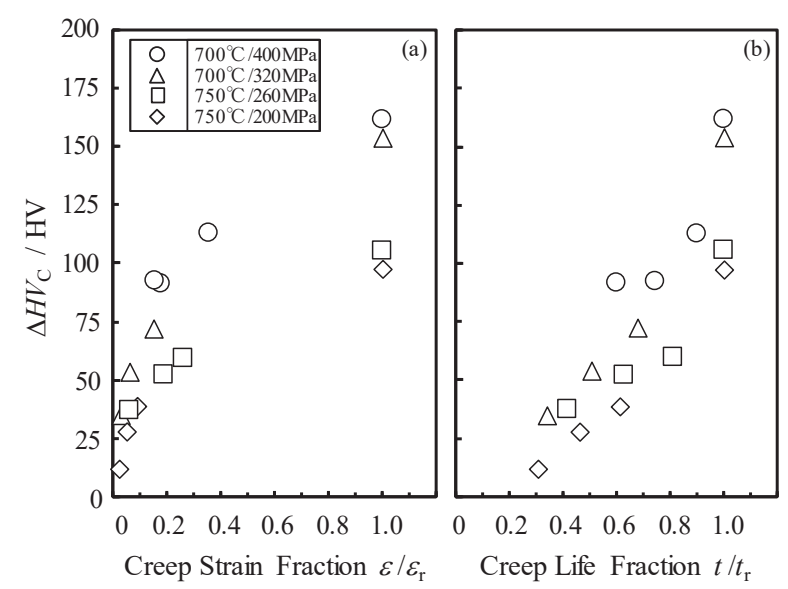

Fig. 7 Hardness increase, $\Delta H V_{\mathrm{C}}$, at gauge portions of specimens crept at $700^{\circ} \mathrm{C}$ and $750^{\circ} \mathrm{C}$ sorted by (a) $\varepsilon / \mathcal{E}_{\mathrm{r}}$ and (b) $t / t_{\mathrm{r}}$.

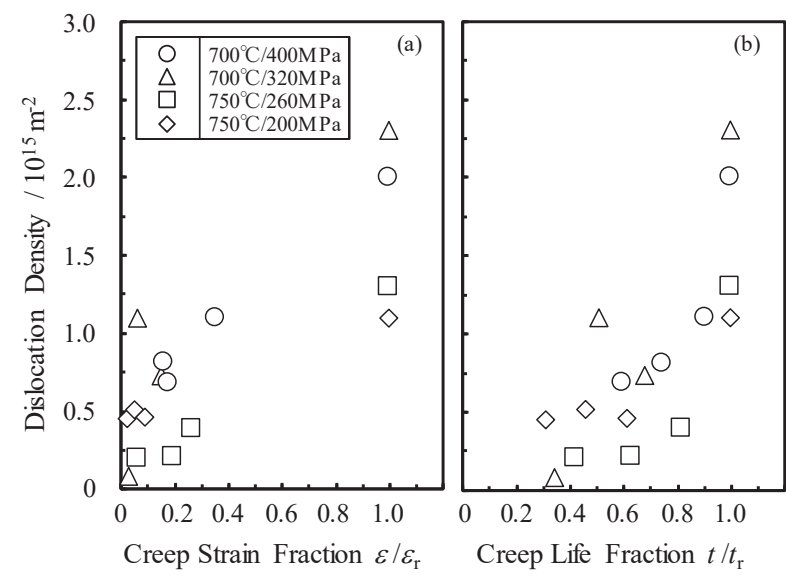

Fig. 8 Dislocation density, $\rho$, at gauge portions of specimens crept at $700^{\circ} \mathrm{C}$ and $750^{\circ} \mathrm{C}$ sorted by (a) $\varepsilon / \mathcal{E}_{\mathrm{r}}$ and (b) $t / t_{\mathrm{r}}$.

$\Delta H V_{\mathrm{c}}$ は格子ひずみ $\varepsilon$ と線形関係にあることがわかる. 転位密度 $\rho$ の $1 / 2$ 乗は，(2)式より格子ひずみ $\varepsilon$ と線形比 例の関係にあることからもわかるように, $\Delta H V_{\mathrm{c}}$ と $\rho$ の $1 / 2$ 乗も直線関係にある. 以上の結果より硬さ増分と転位密 度の間には Bailey-Hirsch の関係が成り立ち, クリープ損 傷材の硬化は加工硬化により説明できる.

\section{$4 \cdot 2$ 加工硬化に基づくクリープ余寿命の推定}

前節までに明らかにしたように，クリープ損傷部の硬 化は当該部の加工硬化量, すなわちクリープひずみと転 位密度に影響され，破断寿命との直接的な関係はなさそ うである. 一方, クリープひずみと時間の関係は実験デー タやクリープ構成式の取得によって求められる. 寸なわ ち, 実機の硬さを測定することによってクリープひずみ を推定し, 推定したクリープひずみからクリープ時間を 推定することが可能と考える.

まず, 加工硬化機構に基づき, クリープによるマクロな ひずみ $\varepsilon_{\mathrm{c}}$ が，転位密度測定における格子ひずみ $\varepsilon$ に比例 すると仮定して，(3)式の転位密度 $\rho$ に(2)式を代入すると， 以下のようになる。

$$
\tau=\alpha G b \sqrt{16.1\left(\frac{\varepsilon_{C}}{b}\right)^{2}}=4.0 \alpha G \varepsilon_{C}
$$

ここで, 定常クリープひずみ速度 $\dot{\varepsilon}_{C}$ は一般的に試験温 度 $T$ および応力 $\sigma$ を含む以下の式(5)で表される.

$$
\dot{\varepsilon}_{C}=A \sigma^{n} \exp \left(-\frac{Q}{R T}\right)
$$

ここで $A$ は材料定数, $Q$ はクリープの活性化エネルギ 一, $R$ は気体定数である.クリープひずみを与える構成式 は，遷移クリープ域や加速クリープ域を含む多数の形式 が存在するが，今回は簡易的に定常クリープのみを考慮 する構成式を用いると，加工硬化は式(4)および(5)から， 以下のように求められる.

$$
\tau=\Delta H V_{C}=\beta G \sigma^{n} \exp \left(-\frac{Q}{R T}\right) \cdot t
$$

ここで $\beta$ は材料固有の定数である. 式(6)は, 加工硬化量 すなわち硬さ増分 $\Delta H V_{\mathrm{c}}$, 温度 $T$ および応力 $\sigma$ が既知であ れば, クリープ時間 $t$ を求められることを示している.

Fig.10 に, 式(6)に基づき各クリープ中断材の硬さ増分 $\Delta H V_{\mathrm{c}}$, クリープ条件である温度 $T$ および応力 $\sigma$ から推定 したクリープ寿命比 $\phi c_{\mathrm{est}}=t / t_{\mathrm{r}}$ と, クリープ試験における 実際の寿命比 $\phi c$ を比較して示す. なお, $\phi c$ est $の$ 算出に用 いた破断時間 $t_{\mathrm{r}}$ は, Fig.3 の関係により温度 $T$ および応力 бから推定した破断時間とした. 硬さ増分から推定した寿 命比は, 実際の寿命比と \pm 0.3 の範囲で一致していた. 寿 命比が 0.8 を超える加速域において若干の乘離が生じる が，クリープ構成式に加速クリープ項を加えることによ って改善されると考えられる. 以上の結果は, 本推定方法 がクリープ余寿命を高い精度で推定可能であり, 加工硬 化機構に基づく推定法が妥当であることを示唆している. 本研究の測定結果および推定方法に基づけば，診断対 象とする部位の硬さを高精度に測定することによって， 使用温度および応力の情報から, 高精度な余寿命推定が 可能であると期待される. しかし, 実機における硬さ測定 は, 姿勢, 表面状態や装置の制約などにより, 一般的に実 験室の理想状態で測定した硬さよりもばらついてしまう 
ため，実機測定硬さの精度向上や適切な統計処理が必要 となる. 本研究の対象となる析出強化型 $\mathrm{Ni}$ 基合金の場合, 結晶粒界と粒内，または結晶粒の方位により，クリープひ ずみの分布が不均一になる可能性がある。したがって, 圧 痕サイズは結晶粒を数個以上含むことが有効であり，十 分に大きな荷重設定にて測定することが理想であると考 えられる，さらに，測定表面における酸化被膜や，切削に よる加工変質層の除去も, 測定值の信頼性を向上させる 上で有効である．硬さ法による寿命推定精度を向上させ るためには, 寿命診断する対象物や状況制約の中で, 上記 のような測定精度を向上する対策を講じることが重要で ある。

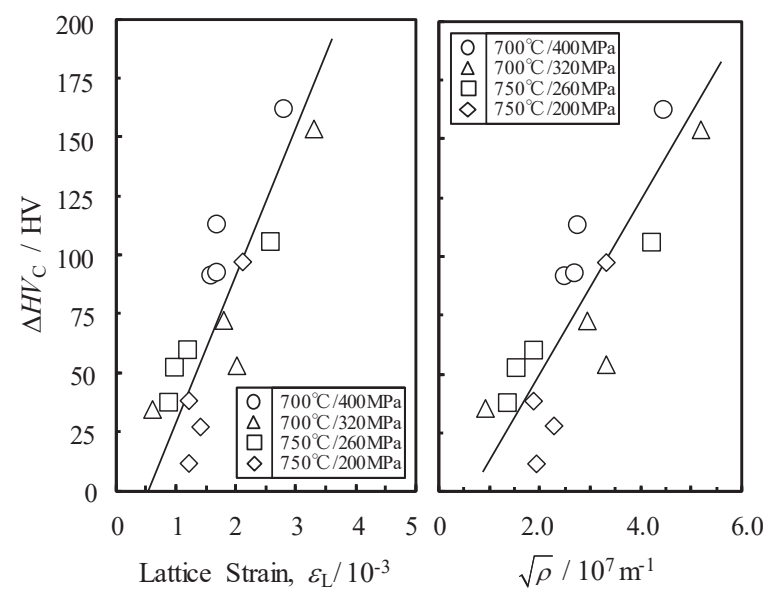

Fig. 9 Relationship between vickers hardness and (a) Lattice strain, (b) square root of dislocation density.

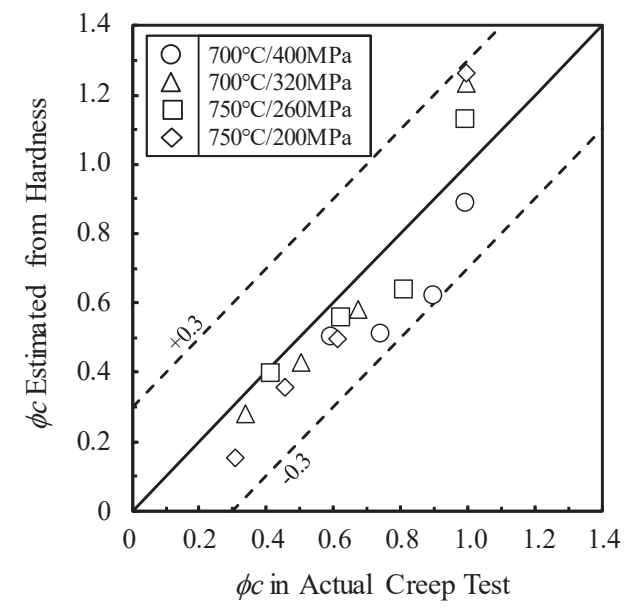

Fig. 10 Relationship between actual $\phi c$ in creep test and estimated $\phi c$ from hardness measurement.

\section{5 結 言}

本研究では，析出強化型 $\mathrm{Ni}$ 基合金のクリープ損傷機 構に基づく余寿命推定法を構築することを目的とし， 複数条件のクリープ中断試験および破断試験片の組織, 転位密度，硬さを系統的に評価し，以下の結論を得た。

(1) 試験片平行部における硬さ増分 $\Delta H V_{\mathrm{c}}$ および転位密度 $\rho$ は，クリープひずみおよび時間の増加に伴い増加す
る.クリープにより導入された転位は $\gamma$ 母相に認め られることから, 変形は $\gamma$ 母相が担うと考えられる.

(2) 硬さ増分 $\Delta H V_{\mathrm{c}}$ と転位密度 $\rho$ の 1/2 乗の間には BaileyHirsch の関係が成り立つことから, クリープ損傷材の 硬化は転位の導入による加工硬化により説明可能で あると考えられる。

(3) 加工硬化に基づき, 測定される硬さ増分, 試験温度お よび応力からなるクリープ余寿命推定式を作成し，ク リープ損傷材の余寿命を高い精度で推定した。

本論文に掲載した商品名称は，それぞれ各社が商標と して使用している場合があります。

本研究は経済産業省補助事業および, 国立研究開発法 人新エネルギー産業技術総合開発機構の助成事業の結果 得られたものです。ここに特記して謝意を表します.

\section{参 考 文 献}

1) D. Gianfrancesco, "Materials for ultra-supercritical and advanced ultra-supercritical power plants", Woodhead Publishing, Duxford, pp.641 (2017).

2) "World Energy Outlook 2016", International Energy Agency, Paris, pp. 31-55 (2016).

3) R. Romanosky, V. Cedro, III, R. Purgert, J. N. Phillips, H. Hack, P. Weitzel, J. Pschirer and J. Claeys, "United States advanced ultra-supercritical component test facility with $760^{\circ} \mathrm{C}$ superheater and steam turbine", Proc. 8th Int. Conf. of Advances in Materials Technology for Fossil Power Plants (EPRI 2016), ed. by J. Parker et al., ASM International, Ohio, pp.1-11 (2016).

4) M. Fukuda, T. Yoshida, A. Iseda, H. Semba, E. Saito, M. Kitamura, T. Dohi, H. Aoki, K. Muroki, H. Fukutomi, K. Sato, K. Takahashi, N. Saito, Y. Hirakawa, T. Nishii, T. Takahashi, T. Takano, Y. Matsubara and Y. Yagi, " $700^{\circ} \mathrm{C}$ A-USC technology development in Japan”, Proceedings of 8th International Conference of Advances in Materials Technology for Fossil Power Plants (EPRI 2016), ed. by J. Parker et al., ASM International, Ohio, pp.12-23 (2016).

5) Z. Liu, "Status of the power industry in China and overall progress for A-USC technology", Proceedings of 8th International Conference of Advances in Materials Technology for Fossil Power Plants (EPRI 2016), ed. by J. Parker et al., ASM International, Ohio, p.24-34 (2016).

6) F. Abe, "Research and development of heat-resistant materials for advanced USC power plants with steam temperatures of $700^{\circ} \mathrm{C}$ and above", Engineering, Vol.1, Issue 2, pp.211-224 (2015).

7) METI, (accessed 2018-10-30) http://www.meti.go.jp/ committee/kenkyukai/energy_environment/jisedai_kary oku/pdf/005_05_00.pdf.

8) K. Sawada, K. Maruyama, R. Komine and Y. Nagae, "Microstructural changes during creep and life 
assessment of Mod.9Cr-1Mo steel", Tetsu-to-Hagané, Vol.83, No.7, pp.466-471 (1997).

9) Y. Kadoya, Y. Hirakawa, H. Yoshida and K. Miyajima, "Creep life evaluation based on hardness method of highCr ferritic steels", Tetsu-to-Hagané, Vol.92, No.2, pp.97104 (2006).

10) M. Kitagawa, "Assessment techniques of the degradation of high temperature plant materials", Journal of the Japan Welding Society, Vol.59, No.3, pp.190-198 (1990).

11) F. Masuyama, K. Ishiyama and T. Yamaguchi, "Creep degradation assessment of Ni-based alloys by hardness method", Proceedings of 8th International Conference of Advances in Materials Technology for Fossil Power Plants (EPRI 2016), ed. by J. Parker et al., ASM International, Ohio, pp.137-148 (2016).

12) F. Masuyama, K. Ishiyama and T. Yamaguchi, "Life assessment and diagnose by hardness response to creep degradation of Alloy 617 and HR6W", Proceedings of 42nd MPA Seminar, Stuttgart, Germany, (2016).

13) S. Zhang and Y. Takahashi, "Evaluation of creep deformation and rupture behaviors of Alloy $740 \mathrm{H}$ and Alloy 617”, Materials Science Research Laboratory Report No.Q14011, CRIEPI, Tokyo, pp.1-18 (2015).

14) Y. Mukai, "X-ray diffraction study on inelastic deformation behavior of Ni-base single crystal superalloy", Proceedings of 21st European Conference on Fracture (ECF21, 2016), pp.895-902 (2016).

15) S. Umezaki, Y. Murata, K. Nomura and K. Kubushiro, "Quantitative analysis of dislocation density in an austenitice steel after plastic deformation”, Journal of The Japan Institute of Metals and Materials, Vol.78, No.6, pp.218-224 (2014).

16) S. Miyashita, K. Nemoto, S. Oinuma, R. Takaku, K. Imai and T. Suga, "Development and evaluation of Ni-based superalloys for large-scale components of A-USC steam turbine", Proceedings of International Gas Turbine Congress, Gas Turbine Society of Japan, Tokyo, pp.46-51 (2015).

17) S. Miyashita, Y. Yoshioka and T. Kubo, "Development and evaluation of large-scale rotor forging for over $700^{\circ} \mathrm{C}$ -class A-USC steam turbine", Proceedings of 7th International Conference of Advances in Materials Technology for Fossil Power Plants (EPRI 2013), ed. by D. Gandy et al., ASM International, Ohio, pp.436-447 (2014).

18) G.K. Williamson and W.H.Hall, "X-ray broadening of from filed aluminum and wolfrm", Acta Metallurgica, Vol.1, pp22-31 (1953).

19) G.K. Williamson and R.E.Smallman, "Dislocation densities in some annealed and cold-worked metals from measurements on the X-ray debye-scherrer spectrum", The Philosophical Magazine, Vol.1, pp34-46 (1956).

20) D. Akama, T. Tsuchiyama and S. Takaki, "Evaluation of dislocation density in cold-worked iron as measured via X-ray diffractometry", Journal of the Society of Materials Science, Japan, Vol.66, No.7, pp.522-527 (2017).

21) Y. Yoshioka, Kyoto University, Ph.D.thesis (1995).

22) K. Marukawa and T. Ohmura, "Dislocation theories applied to the elucidation of mechanisms of metal strengthening", Tetsu-to-Hagané, Vol.100, No.9, pp.1076-1088 (2014).

23) M. Kumagai, T. Kikuchi, M. Imafuku and S. Ohya, "Evaluation of microstructures and mechanical properties of steel with tensile loading process using Xray line profile analysis", Tetsu-to-Hagané, Vol.99, No.5, pp.366-372 (2013). 